\title{
Resilient but not sustainable? Public perceptions of shale gas development via hydraulic fracturing
}

\author{
Darrick Evensen $^{1}$, Richard Stedman ${ }^{2}$ and Benjamin Brown-Steiner ${ }^{3}$
}

\begin{abstract}
Complex energy development, such as associated with extraction and processing of shale gas, may affect the future sustainability and resilience of the small, often rural communities where development occurs. A difficulty for understanding the connection between sustainability, resilience, and shale gas development (hereafter "SGD") is that definitions of sustainability and resilience are often muddled and unclear. Nevertheless, the ways in which development could affect sustainability and resilience have been discussed and contested in academic literature. Little is known, however, about the general public's thoughts on how SGD relates to sustainability and resilience. Despite the overlap and conflation of these two concepts, research indicates some differences between characterizations of the two. While acknowledging difficulties in defining the terms, we included questions on a few broad attributes of the two concepts in a survey $(n=1202)$ of a random sample of residents in the Marcellus Shale region of NY and PA, to explore the relationship between support for / opposition to SGD and perceived importance of community sustainability and resilience. Our survey revealed that beliefs about the importance of sustainability, as measured by three items that clearly pool together as a single factor, are associated with opposition to SGD; beliefs about the importance of resilience, measured by four clearly connected items, are associated with support for SGD. This finding is particularly intriguing and relevant for communication and policy about sustainability and resilience in connection with energy development, because of the common conflation of the two terms.
\end{abstract}

Key Words: hydraulic fracturing; perceptions; resilience; shale gas; sustainability

\section{INTRODUCTION}

Shale gas development via hydraulic fracturing, often called "fracking," has strong potential to affect environmental, economic, and social well-being in communities throughout the USA and the world (Davis and Robinson 2012, Adgate et al. 2014, Jacquet 2014). Shale gas development (hereafter "SGD") is an increasingly prominent and controversial political issue in the USA, Canada, much of Europe, and beyond (Mazur 2014, Williams et al. 2015, Thomas et al. 2016). Research on this topic has proliferated exponentially over the last half decade; much research focuses on impacts associated with development (Sovacool 2014). Scientists have afforded particular attention to effects on the following: (1) water quality (Entrekin et al. 2011, Jackson et al. 2013, Olmstead et al. 2013, Vidic et al. 2013, Vengosh et al. 2014, Llewellyn et al. 2015), (2) air quality (Moore et al. 2014), (3) global climate change (Alvarez et al. 2012, Allen et al. 2013, Newell and Raimi 2014), (4) biota/ecosystems (Drohan et al. 2012, Kiviat 2013, Souther et al. 2014, Milt et al. 2015), (5) human health (New Brunswick Department of Health 2012, Kibble et al. 2013, Adgate et al. 2014, Kovats et al. 2014, Maryland Institute for Applied Environmental Health 2014), (6) local and regional economics (Kinnaman 2011, Weber 2012, Fry et al. 2015), and (7) community well-being (Jacquet 2014, Jacquet and Stedman 2014, Evensen 2015). These impacts could contribute to or challenge the prospects for sustainable and resilient futures in the communities where they are experienced.

Mass media offer quotidian coverage of the topic of fracking and its potential effect on national and global energy futures. For example, on the morning we finalized this article, news coverage from the BBC (2016) examined the role shale gas development in the UK could play in contributing to reductions in global greenhouse gas emissions or exacerbating this problem. This issue of shale gas's effect on the global carbon budget has attracted substantial attention in public and academic discourse because of ever-increasing attention to the effects of climate change and the need to reduce emissions, especially since the Paris climate agreement that was signed in December 2015 and entered in force in November 2016.

Researchers have debated the following: (1) the lifecycle emissions of shale gas versus coal (Howarth et al. 2011, Wigley 2011, Weber and Clavin 2012, Jenner and Lamadrid 2013), (2) rates of methane leakage from wellhead production and transmission infrastructure (Alvarez et al. 2012, Allen et al. 2013, Sanchez and Mays 2015), (3) the extent to which gas actually displaces coal use globally (Sovacool 2014), (4) 20-versus 100-year time frames for warming potential (Cathles et al. 2012, Howarth et al. 2012), (5) surface versus airborne methane measurements (Zavala-Araiza et al. 2015), (6) the effect of lowered energy prices on gas consumption (Newell and Raimi 2014), (7) competition between low-cost gas and renewables/carbon capture and storage (Schrag 2012), and the role of shale gas as a "bridge fuel" (Duggan-Haas et al. 2013, Gilbert and Sovacool 2014, Evensen 2016a). There is currently no scientific, political, or public consensus on whether shale gas development exacerbates or mitigates climate change, but strong evidence exists that public perceptions of shale gas's effect on climate change directly relates to support for/opposition to development, at least in Europe (O'Hara et al. 2016).

Beyond the role of shale gas in shaping our energy future through its relationship to climate change, governments (particularly in Europe) have advocated for shale gas because of the role it could play in advancing energy independence, often called energy security in the U.S. (HM Treasury 2016, Sagener 2016). National and European arguments about such broad goals, however, have

${ }^{1}$ School of Psychology, Cardiff University, ${ }^{2}$ Human Dimensions Research Unit, Department of Natural Resources, Cornell University, ${ }^{3}$ Joint Program on the Science and Policy of Global Change, Massachusetts Institute of Technology 
clashed with claims that policy on SGD does not give enough authority to local communities to govern development and mitigate attendant impacts (Cotton 2016). This line of argumentation is rooted in distributive and procedural justice claims about SGD (Evensen 2016b) and the place-based nature of many impacts associated with development (Jacquet 2014, Fernando and Cooley 2016, Jerolmack and Berman 2016, Kroepsch 2016, Sangaramoorthy et al. 2016).

The rootedness of many impacts of SGD in rural communities makes the concepts of sustainability and resilience particularly relevant to this form of natural resource development. Sustainability and resilience are two core constructs associated with well-being, particularly in resource-dependent communities (Beckley et al. 2002, Scott 2012). Although politicians, government entities, industry groups, academics, and environmental groups have frequently employed the language and/or concepts of sustainability and resilience in supporting or opposing SGD (Weigle 2011, Clarke et al. 2012, Hughes 2013, Mazur 2014, Wang et al. 2014, Williams et al. 2015), no academic research to our knowledge has sought to establish the degree to which a connection exists between the general public's thoughts about SGD and attributes of sustainability or resilience. Herein, we present results from a representative survey of residents from the Marcellus Shale region in southern New York State and northern Pennsylvania, USA. Our data analysis links perceived importance of attributes of sustainability and of resilience to support for/opposition to SGD. Broadly, we find that opponents of SGD are more likely to specify the importance of attributes of sustainability, while supporters of SGD are more likely to indicate the importance of attributes of resilience. We discuss possible explanations for these results and consider their implications for policy and communication about SGD.

\section{Sustainability and resilience}

While fully explicating and integrating decades of definitions offered for sustainability and resilience is beyond the remit or capacity of this article, we offer here an introduction to the range, diversity, and overlap of definitions for the two concepts.

\section{Sustainability}

Sustainability is notorious as an extremely poorly defined and operationalized concept (Böhringer and Jochem 2007, Wilson et al. 2007, Davidson 2010, Mori and Christodoulou 2012). For example, differing measures of national sustainability have placed the same nation in the top five in the world on one metric while in the bottom five in the world on a different metric (Wilson et al. 2007). Common definitions range from proverb-like maxims (see Lyons's Opening Statement to the United Nations "The Year of Indigenous Peoples" in Johansen 2010) to abstract principles and complex mathematical equations (Arrow et al. 2004, Ulanowicz et al. 2009). Yet, the wealth of academic attention to sustainability also confirms the generally agreed upon importance of measuring and understanding sustainability for policy making and public communication (Singh et al. 2009).

Even as a standard definition remains elusive, some generally agreed upon characteristics can be gleaned from previous work. From even before the seminal 1987 Brundtland Report, the needs of future generations were considered in definitions of sustainability (Allen 1980). Virtually all work on sustainability additionally acknowledges the necessity of accounting for environmental, economic, and social indicators of well-being (Mori and Christodoulou 2012). Mori and Christodoulou (2012) and Moldan and colleagues (2012) provide additional basic characteristics of sustainability that this construct could be checked against (see Table 1).

Table 1. Attributes of sustainability and resilience.

\begin{tabular}{l}
\hline Attributes of Sustainability \\
Consideration of present and future consequences ${ }^{\dagger}$ \\
Acknowledgment of uncertainties ${ }^{\dagger}$ \\
Engagement of the public \\
Consideration of equity \\
Understanding of nonlinear evolution (e.g., thresholds, \\
tipping points) \\
Taking feedbacks (positive and negative) into account \\
Regard for different time scales \\
Flexibility (to react to changing situations) \\
Respect for living nature \\
Attributes of Resilience \\
Capacity to absorb shocks and still maintain function \\
Capacity for renewal, reorganization, and development \\
Sustained diversity and individuality of components \\
Localized interactions among those components \\
Ability to plan, learn, and reorganize \\
Perception of the ability to cope with changel \\
The level of interest in adapting to change \\
The perception of risk in approaching changel
\end{tabular}

${ }^{\dagger}$ Mori and Christodoulou (2012), ${ }^{\ddagger}$ Moldan et al. (2012), ${ }^{\S}$ Folke (2006), ' Marshall and Marshall (2007)

\section{Resilience}

The concept of resilience has also been muddled by many definitions. Resilience has been studied and promoted for over four decades (Holling 1973); in the 1960s and 1970s it emerged in relation to ecological processes. Starting in the 1990s, resilience was applied more holistically to social-ecological systems (Costanza et al. 1993, Berkes and Folke 1998, Berkes et al. 2003, Davidson-Hunt and Berkes 2003). In a review of literature on resilience as a tool for analyzing social-ecological systems, Folke (2006) and Marshall and Marshall (2007) highlight major ways in which resilience has been defined and operationalized (see Table 1).

Folke (2006:259) defines resilience as "the capacity of a system to absorb disturbance and re-organize while undergoing change so as to still retain essentially the same function, structure, identity and feedbacks." Similarly, Folke and colleagues (2002:437) offer the following definition, "the capacity to buffer change, learn and develop." Lebel and colleagues (2006) explain resilience as "a measure of the amount of change a system can undergo and still retain the same controls on structure and function or remain in the same domain of attraction." Folke (2006:259) explicitly links resilience to "adaptive capacity" and offers that "it is also about the opportunities that disturbance opens up in terms of recombination of evolved structures and processes." A unifying theme across these definitions is the ability to deal with change gracefully. 
Table 2. Importance of sustainability and resilience to community future. "How important do you think the following are to a positive future for communities like yours?" Please check one per row. ${ }^{\dagger}$

\begin{tabular}{|c|c|c|c|c|c|c|c|}
\hline & $\begin{array}{l}\text { Not at all } \\
\text { important }\end{array}$ & $\begin{array}{c}\text { Not very } \\
\text { important }\end{array}$ & $\begin{array}{c}\text { Moderately } \\
\text { important }\end{array}$ & Important & $\begin{array}{c}\text { Very } \\
\text { important } \\
\end{array}$ & $\begin{array}{l}\text { Extremely } \\
\text { important } \\
\end{array}$ & Mean \\
\hline $\begin{array}{l}\text { Being a community that can "reinvent" } \\
\text { itself }\end{array}$ & 3 & 7 & 16 & 38 & 22 & 14 & 4.12 \\
\hline $\begin{array}{l}\text { Integrating economic, environmental, } \\
\text { and social issues in decision making }\end{array}$ & 1 & 2 & 9 & 36 & 30 & 22 & 4.58 \\
\hline $\begin{array}{l}\text { Being able to absorb and adapt to } \\
\text { change }\end{array}$ & 1 & 2 & 12 & 40 & 28 & 17 & 4.43 \\
\hline $\begin{array}{l}\text { Considering future consequences of } \\
\text { decisions }\end{array}$ & 0 & 0 & 4 & 25 & 29 & 41 & 5.05 \\
\hline Having a diverse economy & 1 & 2 & 12 & 38 & 28 & 19 & 4.45 \\
\hline $\begin{array}{l}\text { Understanding "tipping points" in how } \\
\text { much stress the local environment can } \\
\text { handle }\end{array}$ & 1 & 2 & 7 & 29 & 24 & 37 & 4.85 \\
\hline
\end{tabular}

${ }^{\dagger}$ The numbers in this table represent the percentage of respondents who selected each variable in each category. The final column presents the mean (average) value for each variable, based on the six-point (1-6) scale.

\section{Linking and differentiating the two}

The aforementioned research literature clearly connects sustainability and resilience in important and notable ways. Indeed, Folke and colleagues (2002:253) explicitly link the concepts when they write, "Another aspect of resilience concerns the capacity for renewal, re-organization and development, which has been less in focus but is essential for the sustainability discourse." Similarly, Lebel and colleagues (2006) assert, "In situations in which uncertainties and change are key features of the ecological landscape and social organization, critical factors for sustainability are resilience, the capacity to cope and adapt, and the conservation of sources of innovation and renewal." As a third example of the overlap between the concepts, Walker and Salt (2006:9) assert, "The bottom line for sustainability is that any proposal for sustainable development that does not explicitly acknowledge a system's resilience is simply not going to keep delivering the goods (or services). The key to sustainability lies in enhancing the resilience of social-ecological systems." Even in relation to SGD specifically, these concepts are amalgamated; Adgate and colleagues (2014:8314) assert, "Community resilience, defined as the ability of a community to sustainably utilize available resources to withstand, respond to, and/or recover from adverse events, may be affected by UNG [unconventional natural gas] development." Several of these definitions see resilience as a key aspect of sustainability, while the final one characterizes "sustainable use" as part of resilience.

The concepts of sustainability and resilience, nevertheless, remain distinct in some ways because of sustainability's greater focus on maintaining (e.g., maintaining well-being, maintaining nature's services at a suitable level) and resilience's enhanced attention to absorbing changes while persisting and managing by change (Davidson 2010). A useful way to highlight differences in the concepts might be through their antonyms: unsustainable for sustainability, vulnerable for resilience.

For the purposes of our study, a sufficient summary is that the terms sustainability and resilience are often afforded multiple meanings, some of which are unclear and some of which parallel closely the other term. Despite the overlap and/or conflation of the two concepts, distinct differences remain. By focusing on repeatedly asserted and frequently accepted characterizations of each concept in our research, we sought to test the relationship between perceived importance of both concepts and support for or opposition to SGD.

\section{METHODS}

To investigate the ways in which perceived importance of sustainability and resilience relates to perceptions of SGD, we included in a survey of residents in the Marcellus Shale region multiple variables that asked respondents about the importance of aspects of sustainability or resilience in communities like theirs. We selected the wording for these variables based on the foregoing review of academic literature on sustainability and resilience (see Table 1). The survey contained three statements for each construct that captured core aspects of sustainability and resilience. We ultimately operationalized sustainability with the second, fourth, and sixth statements in Table 2; the first, third, and fifth statements in Table 2 operationalized resilience. Additionally, the second statement, which we primarily selected to characterize sustainability, also speaks clearly to the commonly proffered definitions of social-ecological resilience.

We included these items in a survey with several other questions designed to measure public attitudes and beliefs about SGD. The only other item analyzed in this article was a question that asked respondents: "Considering everything, do you support or oppose shale gas development in the following areas?" (Areas: in your community, in your state, in the USA). For analysis, we combined these three measures of support/opposition into a single variable because of extremely high factor loadings between the measures.

We mailed the survey to a stratified random sample of residents in 34 municipalities in the Marcellus Shale region of southern New York and northern Pennsylvania (17 municipalities in each state, total $\mathrm{N}=1202$ ). Each of these communities has either seen substantial development already or was in an area with legitimate 
potential for development. While NY State had a moratorium on SGD at the time of the survey, the full ban in NY was not instated until December 2014, meaning that the respondents in both states could readily be exposed to development and its attendant effects. Discourse about SGD was palpable and heated in all areas surveyed; many of the municipalities had enacted legislation supporting or opposing development.

The sample frame was compiled by cross-referencing the most recently available U.S. Postal Service records with telephone book white pages. We were able to exclude seasonal addresses, addresses that had been vacant for over 90 days, and "drops" (single delivery points that service multiple residences) from the sample frame. We included all other address types, i.e., regular street addresses, PO boxes, street addresses that actually go to PO boxes, rural routes, and deliveries contracted out to third parties by the USPS. We mailed surveys in a four-wave mailing, i.e., survey, reminder, second survey, second reminder.

Data collection for this survey occurred during OctoberNovember 2013. We contracted with an independent research firm to conduct a telephone nonrespondent follow-up survey, to occur in late November 2013. The nonrespondent follow-up sample included 150 completed interviews, 75 each from residents in NY and residents in PA. We incorporated a subset of the questions from the original survey in this follow-up survey. Both the sample and the nonrespondent follow up varied from population means in terms of age, sex, and education. The sample was more educated, more male, and older than the general population in this region. Therefore, we used 2010 U.S. Census data for the six counties in NY (averaged across these counties) and four counties in PA (again, averaged) to generate proportional weights, based on age, sex, education, and state, which we applied to the data set for all subsequent analysis.

\section{RESULTS}

Overall, our respondents believed that attributes of sustainability and resilience are important for positive futures in their communities (Table 2); the lowest mean response was 4.12, equivalent to between "important" and "very important" on our six-point scale. All measures of sustainability displayed higher means than each measure of resilience. Additionally, a higher percentage of individuals considered each measure of sustainability to be "extremely important," compared to each measure of resilience.

For all subsequent analysis, save the structural equation modeling, we used IBM SPSS Statistics, version 23 (2015). Our first multivariate analysis was an exploratory factor analysis of the six items (principal axis factoring with promax [oblique] rotation because of suspected correlation between the factors). We tested for separation of the resilience and sustainability attributes into individual constructs; two distinct factors emerged as predicted. The highest cross-loading between factors had an absolute value of 0.11 , not counting the one item intended to load on both factors, i.e., "integrating economic, environmental, and social issues in decision making." The eigenvalues were 3.31 for resilience and 1.14 for sustainability, leading to an explained variance of $55.1 \%$ and $18.9 \%$, for a total of $74.0 \%$. A reliability analysis of the four items in resilience produced a Cronbach's alpha of 0.832 . A reliability analysis of the three items in sustainability produced a Cronbach's alpha of 0.794 . The data from this factor analysis and these reliability analyses confirm the strong separation into two distinct concepts of the items intended to measure sustainability and resilience.

Following the exploratory factor analysis, we conducted a linear regression to test the relationship between support/opposition and the two factors. We created composite variables for sustainability and resilience by averaging the values of the component items. We then regressed these two composite variables on a composite variable for support/opposition, i.e., a variable that averaged responses on support/opposition across community, state, and USA. The results of this regression provided a strong indication that support for development is associated with beliefs about the importance of resilience (standardized beta coefficient of $0.49, \mathrm{p}<0.001$ ), and that opposition to development is associated with beliefs about the importance of sustainability (standardized beta coefficient of $-0.58, \mathrm{p}<0.001$; because the question on support/opposition contained a six-point scale 1 equal to strongly oppose and 6 equal to strongly support, a negative beta coefficient equates to increased opposition). The model adjusted $\mathrm{R}^{2}$ - the amount of variance in support/opposition explained by the two independent variables - was 0.29 , i.e., $29 \%$ of variance explained.

We next designed two structural equation models (SEMs), which effectively combine regression pathways with (confirmatory) factor analyses. For SEM analysis, we used Mplus, version 7.3 (2014). In our SEMs, we specified the causal directionality of the regression pathways between support/opposition and sustainability/ resilience in reverse from the linear regression (see Fig. 1). We believe it makes greater theoretical sense to posit that support/ opposition affects resilience and sustainability, than vice versa, because the survey question about these two factors asked "How important do you think the following are to a positive future for communities like yours?" Because of these questions looking into the future, prior experience with and views on SGD would likely be viewed as antecedent. We acknowledge that causality in this relationship cannot be determined with certainty; the relationship likely operates to some extent in both directions (a structural equation model with all the same variables and pathways as in Figure 1, but with the only variation being that the pathways between support/opposition and resilience and sustainability were reversed, still had good fit $[\mathrm{RMSEA}=0.053$, CFI $=0.990$, SRMR $=0.021]$ ). The causal direction of the relationship is not particularly important for our analysis or interpretation here; what matters is that the relationship between importance of sustainability or resilience and support for/opposition to SGD is clear.

Both SEMs contain structural (regression) pathways from the latent variable "support" to the latent variables representing sustainability and resilience (again, for the attribute variables, see Table 2). These pathways reveal that strong relationships exist between support/opposition and respondent beliefs about the importance of sustainability and resilience for a positive future in communities like theirs. In our first model (Fig. 1), the standardized beta coefficients of 0.22 for resilience and -0.42 for sustainability indicate that respondents supporting development find greater importance in the four items making up the resilience factor, whereas respondents opposing development find greater importance in the three items comprising the sustainability factor. 
Fig. 1. Structural equation model; effects of support for/opposition to shale gas development on importance of sustainability and resilience. Rectangular boxes represent measured variables from the survey, ovals represent latent variables generated from the boxes to which the associated arrows point; coefficients on pathways from ovals to boxes represent factor loadings, coefficients on pathways from ovals to ovals represent standardized beta coefficients as in a regression; the curved arrow is an error covariance between the residuals for the latent variables representing sustainability and resilience.

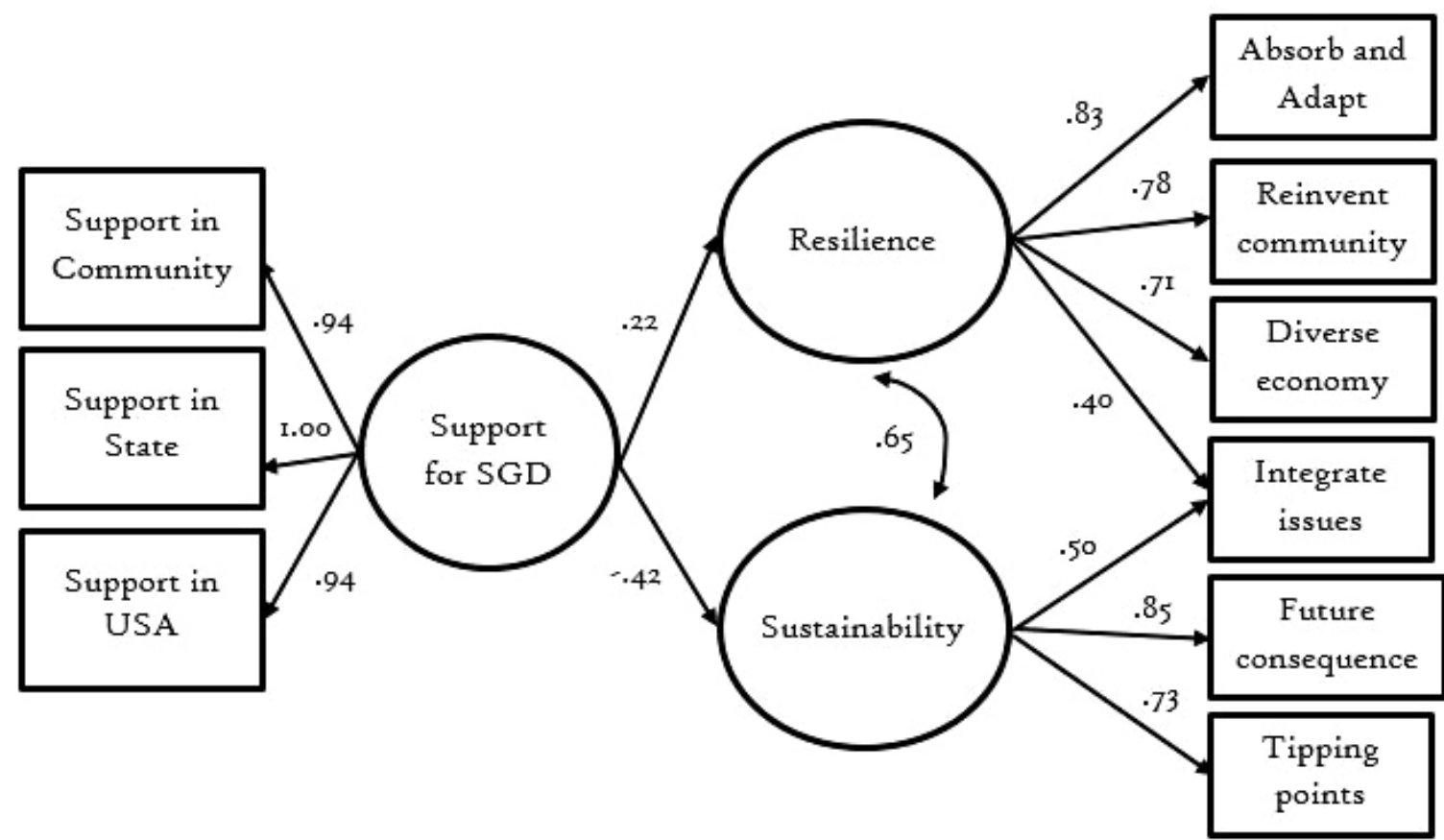

All pathways in Figure 1 are significant at $p<0.01$. The model in Figure 1 equates to Model 1 in Table 3. The second model in Table 3 includes a set of covariates to assess whether these variables, i.e., sex, age, political views, and education, add explanatory power to the model. Although several of the relationships between the covariates and the latent variables are significant, the measures of fit reveal that they do not meaningfully affect the suitability of the model. Both models have excellent fit.

\section{DISCUSSION}

The pathways from support/opposition to the latent variables representing sustainability and resilience in the SEMs, along with the generally strong factor loadings on the component items for sustainability and resilience, demonstrate that people who oppose SGD are more likely to think that sustainability is important for the future of communities like theirs, while people who support SGD are more likely to think that resilience is important. This finding, of course, is based on a characterization of sustainability as (1) integrating economic, environmental, and social issues, (2) considering future consequences, and (3) understanding tipping points, while resilience consists of the following: (1) being able to reinvent one's community, (2) being able to absorb and adapt to change, (3) having a diverse economy, and (4) integrating economic, environmental, and social issues. One could easily argue that aspects of both concepts are not captured in these definitions; yet, the operationalizations do include central aspects of sustainability and resilience offered by the scholars cited in the introduction. It could further be observed that not all of the measures of the two concepts may be equally understandable to the general public; for example, considering future consequences and having a diverse economy might be initially clearer than attributes such as understanding tipping points and being a community that can reinvent itself. Both sustainability and resilience, however, contained clear and more complex measures in the survey, raising the question of whether this could affect our results. Furthermore, the strong split into two factors in the exploratory and confirmatory factor analyses confirms the existence of conceptually distinct items.

The opposite direction of the association of support/opposition with sustainability and resilience is initially surprising, because much scholarly work on the concepts of sustainability and resilience links these two items as working toward similar goals. For example, Folke (2006:260) writes, "The resilience approach provides one among several arenas for generating integrative science and interdisciplinary collaboration on issues of fundamental importance for governing and managing a transition toward more sustainable development paths." Resilience is often seen as leading to sustainable development. Although sustainable development and sustainability are not the same thing, we have not yet heard it suggested that sustainability and resilience are opposed to each other. Nevertheless, support/opposition for development has the opposite relationship with the four attributes of resilience as it does with the three measures of sustainability. 
Table 3. Parameter coefficient estimates and measures of model fit for structural equation models.

\begin{tabular}{|c|c|c|}
\hline Standardized parameter estimates & Model 1 & Model 2 \\
\hline $\begin{array}{l}\text { resilience on support } \\
\text { sustainability on support } \\
\text { resilience on sex }^{\ddagger} \\
\text { sustainability on sex } \\
\text { resilience on age } \\
\text { sustainability on age } \\
\text { resilience on political } \\
\text { sustainability on political } \\
\text { resilience on education } \\
\text { sustainability on education } \\
\text { support on sex } \\
\text { support on age } \\
\text { support on education }\end{array}$ & $\begin{array}{l}0.215^{* * *} \\
-0.416^{* * *} \\
--- \\
--- \\
--- \\
-- \\
--- \\
-- \\
--- \\
--- \\
-- \\
--- \\
---\end{array}$ & $\begin{array}{l}0.257^{* * *} \\
-0.369^{* * *} \\
-0.085^{*} \\
-0.067^{*} \\
-0.040 \\
-0.069^{*} \\
-0.078 \\
-0.040 \\
-0.031 \\
0.129^{* * *} \\
0.114^{* * *} \\
0.340^{* * *} \\
-0.080^{* *}\end{array}$ \\
\hline $\begin{array}{l}\text { Measures of } \text { fit }^{\S} \\
\chi^{2}(\text { d.f. }) \\
\text { CFI } \\
\text { RMSEA } \\
\text { RMSEA }(90 \% \text { C.I. }) \\
\text { SRMR }\end{array}$ & $\begin{array}{l}88.1 * * *(23) \\
0.985 \\
0.049 \\
0.038-0.060 \\
0.022\end{array}$ & $\begin{array}{l}150.6^{* * *}(48) \\
0.981 \\
0.044 \\
0.036-0.052 \\
0.021\end{array}$ \\
\hline \multicolumn{3}{|c|}{$\begin{array}{l}* * * \mathrm{p}<0.001, * * \mathrm{p}<0.01, * \mathrm{p}<0.05 \\
\text { "The word "on" in this table means "regressed on"; for example, } \\
\text { "resilience on support" is read as "the latent variable representing } \\
\text { "importance of resilience' regressed on the latent variable representing } \\
\text { "support for shale gas development"". The variable following the word } \\
\text { "on" is the predictor variable; for example, the beta coefficient for } \\
\text { "resilience on support" explains the degree to which "support" affects } \\
\text { "resilience." } \\
\text { "Variable definitions: "Sex" is a dichotomous variable ( } 0=\text { female, } 1= \\
\text { male); "age" is a linear variable measured in years; "political" is a linear } \\
\text { variable representing political views, measured on a scale from } 1 \text { (very } \\
\text { liberal) to } 7 \text { (very conservative); "education" is an ordinal variable with } \\
\text { five categories ("didn't graduate high school" to "completed graduate } \\
\text { degree"). } \\
\S \text { Measures of fit: " } \chi 2 \text { (d.f.)" = the chi-suqared value (degrees of freedom } \\
\text { in parentheses), CFI = Comparative Fit Index, RMSEA = Root Mean } \\
\text { Square Error of Approximation, RMSEA ( } 90 \% \text { C.I.) }=\text { the } 90 \% \\
\text { confidence interval for the RMSEA, SRMR = Standardized Root } \\
\text { Mean Square Residual. For additional definitions of these measures of } \\
\text { fit, see Hooper et al. } 2008 \text {. }\end{array}$} \\
\hline
\end{tabular}

The finding that higher levels of support for SGD relate to lower perceived importance of sustainability for a community's future, but to higher importance of resilience for a community's future, is intriguing. This novel finding might harken back to a centuryold debate that is epitomized by the conflict between two great figures in the environmental movement in the United States, John Muir and Gifford Pinchot. Muir represented the ideals of the preservationist, while Pinchot displayed those of the conservationist. Muir and the preservationists sought to keep the natural world in its current state, unspoiled and unadulterated; Pinchot and the conservationists thought that using the environment and natural resources available to improve wellbeing, while still keeping the resource in good/useable condition, was the best way to care for the natural environment.

People opposed to SGD may be, in part, displaying ideals associated with preservationists (at least abstractly, in terms of commitment to "preserving" environmental and social states of being), while people supporting SGD reflect, to some extent, values of conservationists, e.g., using resources in a way that changes the landscape but which they believe promotes overall well-being. An additional question in our survey asked respondents to agree or disagree with the following statement: "My community is special to me as it is; I would not want anything to change." The response to this question had a correlation of -0.31 with the support/opposition composite variable (thus, stronger agreement with the statement was associated with stronger opposition) and the variable alone explained $10 \%$ of the variance in responses to the support/opposition composite variable. This provides additional evidence that those opposed to SGD are more committed to maintaining (akin to various academic operationalizations of sustainability), while supporters of SGD are more dedicated to adapting to change (often aligned with resilience).

In response to the aforementioned relationships, one might contest our choice of items measuring sustainability and/or resilience in the survey, or argue that some of our items measuring sustainability also apply to resilience (and vice versa). This is to be expected because of the inability of the academic community to even approach a consensus on the definition of either term. Nevertheless, it is clear that at least some of the attributes that characterize these two terms are conceptually distinct. The exploratory and confirmatory factor analyses revealed clear separation into two distinct factors of the items designed to capture sustainability and resilience; therefore, at least members of the general public differentiate between these attributes. Attributes of resilience common in academic literature, i.e., adsorbing, adapting, diversity, and reinventing, paired with support for SGD, while attributes of sustainability, i.e., understanding tipping points and considering future consequences, paired with opposition to SGD.

SGD is a novel approach to energy resource extraction; we do not claim that the observed bifurcation in support/opposition based on perceived import of sustainability and resilience would necessarily transfer to other contentious environmental and social issues. Nevertheless, the relationship could likely find currency in respect to other fossil fuel development projects that substantially transform the landscape and local communities.

The findings herein could be useful for further interpreting the burgeoning academic literature that links place attachment, place meanings, and place identity to extractive industries that transform rural communities (e.g., Perry 2012, Jacquet and Stedman 2013, 2014, Morrone et al. 2015, Schafft and Biddle 2015, Fernando and Cooley 2016, Jerolmack and Berman 2016, Kroepsch 2016, Sangaramoorthy et al. 2016). This emerging research broadly asserts that place attachment (an emotional bond between people and their environment) and place meanings (thoughts about what kind of place the focal environment is) strongly shape support for or opposition to extractive development.

Although the first decade of social scientific research on SGD attributed support/opposition mostly to perceptions of environmental, economic, and social impacts (see Thomas et al. 2016 for a review), the aforementioned recent work on place attachment and place meanings suggests that it is not the impacts on water quality, roads, and economic development, for example, 
that matter themselves, but rather it is the effect of these impacts on place attachment and place meanings that matters for support/ opposition. The oppositional tendencies of one seeking (or being open to) change or contrastingly seeking to maintain and preserve a place in its current state connect the concepts of resilience/ sustainability and place meanings. If people's definition of their community (place meaning) is of a place needing or benefiting from change, it seems likely they would value resilience and be more open to SGD. If people's place meaning is of an ideal location that is perfectly unique in its peace and aesthetic tranquility, it seems likely they would value sustainability and be opposed to SGD. As Stedman (2016) argues, place attachment and place meanings can help us understand better the social dimension of social-ecological systems; one way in which this could work is through attributes of sustainability or resilience being components of an individual's or community's place meaning.

Finally, we must note that we are not advocating for or critiquing the concepts of sustainability or resilience or their applicability to issues such as SGD. In this article, we merely seek to demonstrate the extent to which and ways in which members of the general public associate perceived importance of these concepts with the controversial issue of SGD. The nature of this relationship has implications for policy on and communication about SGD.

\section{Implications for policy and communication}

\section{Policy}

Both sustainability and resilience are frequently cited as important for policy, particularly for policy on issues with complex environmental, economic, and social implications. The survey results advise that policy constructed to promote sustainability and/or resilience could be well received. Some interviews we have conducted with opinion leaders in communities affected by SGD, however, suggest that the words "resilience" and (particularly) "sustainability" should not be used, because of additional cultural baggage attached to these words; rather, the concepts presented in Table 2 could instead be communicated. Especially in areas where sentiment on this issue is split, policy makers might consider regulation that addresses components of sustainability and resilience; by speaking to both concepts, their messages could appeal to a wider segment of the general public.

The foregoing research highlights the relationship between fundamental values, which will not necessarily be easily changed by additional information about risks and benefits, and support for/opposition to SGD. For example, if local residents in areas slated for development have concerns about future generations, more data about near-term local economic growth and limited water contamination over a relatively short time period might not matter much. If residents care strongly about diverse economic opportunities and the ability for their community to "reinvent" itself, data showing certain levels of environmental contamination and/or induced seismicity might be an acceptable trade-off. Policy on this issue must respond not only to impacts associated with SGD, but also to how and why people value those impacts.

\section{Communication}

Whether one is in favor of SGD, opposed to it, or is simply trying to ensure that the general public is informed on this topic, the concepts of sustainability and resilience could be useful in strategic communication. When communicating with audiences opposed to shale gas development, using the concepts of sustainability (although not necessarily the word "sustainability" itself) for discussing how to move forward on the topic of development could be advantageous. When communicating with audiences supportive of shale gas development, using the concepts of resilience (although not necessarily the word "resilience" itself) to discuss development could be opportune.

Partisans on any side of this issue or people simply interested in forwarding the policy process could benefit from this finding. For example, opponents of SGD seeking to broaden their message to individuals who do not necessarily agree with them might seek to explain why and how they believe SGD undermines aspects of resilience. Alternatively, they may choose to avoid the contentious topic of SGD altogether and seek to explain other actions their community/region/state could take to increase resilience, seeking to reveal that SGD is not the only option for added resilience. Supporters of SGD reaching out to a wider audience could focus on how aspects of sustainability can still be achieved in light of SGD, e.g., by limiting the pace and scale of development.

When communicating to audiences in support or opposition, acknowledging the importance of resilience or sustainability, whichever concept is more relevant to the audience, could be an important first step to approaching a conversation with parties opposed to one's own view on development. Neutral parties simply seeking to further discourse on SGD could use both concepts and explain ways in which aspects of both sustainability and resilience are needed to make decisions on this controversial issue.

\section{CONCLUSION}

The findings herein reveal the following: (1) most of the randomly sampled respondents to the survey in the Marcellus Shale region believe that attributes of sustainability and resilience are important to the future of communities like theirs, but (2) the more respondents support SGD, the more likely they are to think attributes of resilience are important and the less likely they are to think attributes of sustainability are important for a positive future in such communities. Similarly, as respondents increasingly oppose SGD, they are more likely to think attributes of sustainability are important and less likely to think attributes of resilience are important.

These initially surprising findings are intelligible in light of a major factor affecting support for/opposition to shale gas development: the propensity to not want one's community to change, but to remain "as is." This complements recent research that identifies place meanings as an essential factor conditioning support for or opposition to SGD. Sustainability, in many senses, seems inherently more conservative than resilience. For example, "considering future consequences" and "understanding tipping points" as a policy approach would likely lead to greater avoidance of change than "being a community that can reinvent itself" and "being able to absorb and adapt to change." This is consistent with a framing, at least in the minds of the general public, of sustainability being more in line with preservationist considerations while resilience is more consistent with conservationist leanings. 
Responses to this article can be read online at: http://www.ecologyandsociety.org/issues/responses. php/9022

\section{LITERATURE CITED}

Adgate, J. L., B. D. Goldstein, and L. M. McKenzie. 2014. Potential public health hazards, exposures and health effects from unconventional natural gas development. Environmental Science \& Technology 48:8307-8320. http://dx.doi.org/10.1021/es404621d

Allen, D. T., V. M. Torres, J. Thomas, D. W. Sullivan, M. Harrison, A. Hendler, S. C. Herndon, C. E. Kolb, M. P. Fraser, A. D. Hill, B. K. Lamb, J. Miskimins, R. F. Sawyer, and J. H. Seinfeld. 2013. Measurements of methane emissions at natural gas production sites in the United States. Proceedings of the National Academy of Sciences of the USA 110:17768-17773. http://dx.doi. org/10.1073/pnas. 1304880110

Allen, R. 1980. How to save the world. Prentice-Hall, Toronto, Ontario, Canada.

Alvarez, R. A, S. W. Pacala, J. J. Winebreak, W. L. Chameides, and S. P. Hamburg. 2012. Greater focus needed on methane leakage from natural gas infrastructure. Proceedings of the National Academy of Sciences of the USA 109:6435-6440. http:// dx.doi.org/10.1073/pnas. 1202407109

Arrow, K., P. Dasgupta, L. Goulder, G. Daily, P. Ehrlich, G. Heal, S. Levin, K.-G. Mäler, S. Schneider, D. Starrett, and B. Walker 2004. Are we consuming too much? Journal of Economic Perspectives 18:147-172. http://dx.doi.org/10.1257/0895330042162377

BBC. 2016. 'Anything but coal' for energy says former Greenpeace head. BBC News, 2 November. [online] URL: http://www.bbc.co. uk/news/uk-wales-politics-37841379

Beckley, T., J. Parkins, and R. Stedman. 2002. Indicators of forestcommunity sustainability: the evolution of research. Forestry Chronicle 78:626-636. http://dx.doi.org/10.5558/tfc78626-5

Berkes, F., J. Colding, and C. Folke, editors. 2003. Navigating social-ecological systems: building resilience for complexity and change. Cambridge University Press, Cambridge, UK. http://dx. doi.org/10.1017/cbo9780511541957

Berkes, F., and C. Folke, editors. 1998. Linking social and ecological systems: management practices and social mechanisms for building resilience. Cambridge University Press, Cambridge, UK.

Böhringer, C., and P. Jochem. 2007. Measuring the immeasurable - a survey of sustainability indices. Ecological Economics 63:1-8. http://dx.doi.org/10.1016/j.ecolecon.2007.03.008

Cathles, L. III, L. Brown, M. Taam, and A. Hunter. 2012. A commentary on "The greenhouse-gas footprint of natural gas in shale formations" by R. W. Howarth, R. Santoro, and A. Ingraffea. Climatic Change 113:525-535. http://dx.doi.org/10.1007/ s10584-011-0333-0

Clarke, C., D. Evensen, J. Jacquet, and R. Stedman. 2012. Emerging risk communication challenges associated with shale gas development. European Journal of Risk Regulation 3:424-430.
Costanza, R., L. Waigner, C. Folke, and K.-G. Mäler. 1993. Modeling complex ecological economic systems: toward an evolutionary, dynamic understanding of people and nature. BioScience 43:545-555. http://dx.doi.org/10.2307/1311949

Cotton, M. 2016. Fair fracking? Ethics and environmental justice in United Kingdom shale gas policy and planning. Local Environment 1-18. http://dx.doi.org/10.1080/13549839.2016.1186613

Davidson, D. 2010. The applicability of the concept of resilience to social systems: some sources of optimism and nagging doubts. Society and Natural Resources 23:1135-1149. http://dx.doi. org/10.1080/08941921003652940

Davidson-Hunt, I., and F. Berkes. 2003. Nature and society through the lens of resilience: toward a human-in-ecosystem perspective. Pages 53-82 in F. Berkes, J. Colding, and C. Folke, editors. Navigating social-ecological systems: building resilience for complexity and change. Cambridge University Press, Cambridge, UK. http://dx.doi.org/10.1017/cbo9780511541957.006

Davis, J. B., and G. R. Robinson. 2012. A geographic model to assess and limit cumulative ecological degradation from Marcellus Shale exploitation in New York, USA. Ecology and Society 17(2):25. http://dx.doi.org/10.5751/es-04822-170225

Drohan, P. J., M. Brittingham, J. Bishop, and K. Yoder. 2012. Early trends in landcover change and forest fragmentation due to shale-gas development in Pennsylvania: a potential outcome for the northcentral Appalachians. Environmental Management 49:1061-1075. http://dx.doi.org/10.1007/s00267-012-9841-6

Duggan-Haas, D., R. Ross, and W. Allmon. 2013. The science beneath the surface: a very short guide to the Marcellus Shale. Paleontological Research Institution, Ithaca, New York, USA.

Entrekin S., M. Evans-White, B. Johnson, and E. Hagenbuch. 2011. Rapid expansion of natural gas development poses a threat to surface waters. Frontiers in Ecology and the Environment 9:503-511. http://dx.doi.org/10.1890/110053

Evensen, D. 2015. Policy decisions on shale gas development ('fracking'): the insufficiency of science and necessity of moral thought. Environmental Values 24:511-534. http://dx.doi. org/10.3197/096327115X14345368709989

Evensen, D. 2016b. Ethics and 'fracking': a review of (the limited) moral thought on shale gas development. WIREs Water 3:575-586. http://dx.doi.org/10.1002/wat2.1152

Evensen, D. 2016a. US presidential candidates' views on unconventional gas and oil: Who has it right? Energy Research and Social Science 20:128-130. http://dx.doi.org/10.1016/j. erss.2016.06.018

Fernando, F. N., and D. R. Cooley. 2016. Attitudes toward shale oil development in western North Dakota: the role of place based community values in attitude formation. Journal of Rural Studies 46:132-146. http://dx.doi.org/10.1016/j.jrurstud.2016.06.008

Folke, C. 2006. Resilience: the emergence of a perspective for social-ecological systems analyses. Global Environmental Change 16:253-267. http://dx.doi.org/10.1016/j.gloenvcha.2006.04.002

Folke, C., S. Carpenter, T. Elmqvist, L. Gunderson, C. S. Holling, and B. Walker. 2002. Resilience and sustainable development: 
building adaptive capacity in a world of transformations. Ambio 31:437-440. http://dx.doi.org/10.1579/0044-7447-31.5.437

Fry, M., A. Briggle, and J. Kincaid. 2015. Fracking and environmental (in)justice in a Texas city. Ecological Economics 117:97-107. http://dx.doi.org/10.1016/j.ecolecon.2015.06.012

Gilbert, A. Q., and B. K. Sovacool. 2014. Shale gas: better modelling for the energy mix. Nature 515:198. http://dx.doi. org/10.1038/515198b

HM Treasury. 2016. Shale wealth fund: consultation. UK Government, London, UK. [online] URL: https://www.gov.uk/ government/consultations/shale-wealth-fund

Holling, C. S. 1973. Resilience and stability of ecological systems. Annual Review of Ecology and Systematics 4:1-23. http://dx.doi. org/10.1146/annurev.es.04.110173.000245

Hooper, D., J. Coughlan, and M. Mullen. 2008. Structural equation modelling: guidelines for determining model fit. Electronic Journal of Business Research Methods 6:53-60.

Howarth, R. W., R. Santoro, and A. Ingraffea. 2011. Methane and the greenhouse-gas footprint of natural gas from shale formations. Climatic Change 106:679-690. http://dx.doi. org/10.1007/s10584-011-0061-5

Howarth, R. W., R. Santoro, and A. Ingraffea. 2012. Venting and leaking of methane from shale gas development: response to Cathles et al. Climatic Change 113:537-549. http://dx.doi. org/10.1007/s10584-012-0401-0

Hughes, J. D. 2013. Energy: a reality check on the shale revolution. Nature 494:307-308. http://dx.doi.org/10.1038/494307a

Jackson, R. B., A. Vengosh, T. H. Darrah, N. R. Warner, A. Down, R. J. Poreda, S. G. Osborn, K. Zhao, and J. D. Karr. 2013. Increased stray gas abundance in a subset of drinking water wells near Marcellus shale gas extraction. Proceedings of the National Academy of Sciences of the USA 110:11250-11255. http://dx.doi. org/10.1073/pnas. 1221635110

Jacquet, J. B. 2014. Review of risks to communities from shale energy development. Environmental Science \& Technology 48:8321-8333. http://dx.doi.org/10.1021/es404647x

Jacquet, J. B., and R. C. Stedman. 2013. Perceived impacts from wind farm and natural gas development in northern Pennsylvania. Rural Sociology 78:450-472. http://dx.doi. org/10.1111/ruso.12022

Jacquet, J. B., and R. C. Stedman. 2014. The risk of socialpsychological disruption as an impact of energy development and environmental change. Journal of Environmental Planning and Management 57:1285-1304. http://dx.doi.org/10.1080/09640568.2013 .820174

Jenner, S., and A. J. Lamadrid. 2013. Shale gas vs. coal: policy implication from environmental impact comparisons of shale gas, conventional gas, and coal on air, water, and land in the United States. Energy Policy 53:442-453. http://dx.doi.org/10.1016/j. enpol.2012.11.010

Jerolmack, C., and N. Berman. 2016. Fracking communities. Public Culture 28(2):193-214. http://dx. doi.org/10.1215/08992363-3427523
Johansen, B., editor. 2010. Native Americans today: a biographical dictionary. Greenwood, Santa Barbara, California, USA.

Kibble, A., T. Cabianca, Z. Daraktchieva, T. Gooding, J. Smithard, G. Kowalczyk, N. P. McColl, M. Singh, S. Vardoulakis, and R. Kamanyire. 2013. Review of the potential public health impacts of exposures to chemical and radioactive pollutants as a result of the shale gas extraction process. PHE-CRCE-009. Public Health England, London, UK.

Kinnaman, T. C. 2011. The economic impact of shale gas extraction: a review of existing studies. Ecological Economics 70:1243-1249. http://dx.doi.org/10.1016/j.ecolecon.2011.02.005

Kiviat, E. 2013. Risks to biodiversity from hydraulic fracturing for natural gas in the Marcellus and Utica shales. Annals of the New York Academy of Sciences 1286:1-14. http://dx.doi. org/10.1111/nyas. 12146

Kovats, S., M. Depledge, A. Haines, L. E. Fleming, P. Wilkinson, S. B. Shonkoff, and N. Scovronick. 2014. The health implications of fracking. Lancet 383:757-758. http://dx.doi.org/10.1016/ $\underline{\text { S0140-6736(13)62700-2 }}$

Kroepsch, A. 2016. New rig on the block: spatial policy discourse and the new suburban geography of energy production on Colorado's Front Range. Environmental Communication 10:337-351. http://dx.doi.org/10.1080/17524032.2015.1127852

Lebel, L., J. M. Anderies, B. Campbell, C. Folke, S. HatfieldDodds, T. P. Hughes, and J. Wilson. 2006. Governance and the capacity to manage resilience in regional social-ecological systems. Ecology and Society 11(1):19. http://dx.doi.org/10.5751/ es-01606-110119

Llewellyn, G. T., F. Dorman, J. L. Westland, D. Yoxtheimer, P. Grieve, T. Sowers, E. Humston-Fulmer, and S. L. Brantley. 2015. Evaluating a groundwater supply contamination incident attributed to Marcellus Shale gas development. Proceedings of the National Academy of Sciences of the USA 112:6325-6330. http://dx.doi.org/10.1073/pnas.1420279112

Marshall, N. A., and P. A. Marshall. 2007. Conceptualizing and operationalizing social resilience within commercial fisheries in northern Australia. Ecology and Society 12(1):1. http://dx.doi. org/10.5751/es-01940-120101

Maryland Institute for Applied Environmental Health. 2014. Potential public health impacts of natural gas development and production in the Marcellus Shale in western Maryland. School of Public Health, University of Maryland, College Park, Maryland, USA.

Mazur, A. 2014. How did the fracking controversy emerge in the period 2010-2012? Public Understanding of Science 25(2). http:// dx.doi.org/10.1177/0963662514545311

Milt, A. W., T. Gagnolet, and P. R. Armsworth. 2015. Synergies and tradeoffs among environmental impacts under conservation planning of shale gas surface infrastructure. Environmental Management 57:21-30. http://dx.doi.org/10.1007/s00267-015-0592$\underline{Z}$

Moldan, B., S. Janoušková, and T. Hák. 2012. How to understand and measure environmental sustainability: indicators and targets. Ecological Indicators 17:4-13. http://dx.doi.org/10.1016/j. ecolind.2011.04.033 
Moore, C. W., B. Zielinska, G. Pétron, and R. B. Jackson. 2014. Air impacts of increase natural gas acquisition, processing, and use: a critical review. Environmental Science \& Technology 48:8349-8359. http://dx.doi.org/10.1021/es4053472

Mori, K., and A. Christodoulou. 2012. Review of sustainability indices and indicators: towards a new city sustainability index (CSI). Environmental Impact Assessment Review 32:94-106. http:// dx.doi.org/10.1016/j.eiar.2011.06.001

Morrone, M., A. E. Chadwick, and N. Kruse. 2015. A community divided: hydraulic fracturing in rural Appalachia. Journal of Appalachian Studies 21:207-228. http://dx.doi.org/10.5406/ jappastud.21.2.0207

New Brunswick Department of Health. 2012. Chief Medical Officer of Health's recommendations concerning shale gas development in New Brunswick. New Brunswick Department of Health, Fredericton, New Brunswick, Canada. [online] URL: http://www2.gnb.ca/content/dam/gnb/Departments/h-s/pdf/en/ HealthyEnvironments/Recommendations_ShaleGasDevelopment. pdf

Newell, R. G., and D. Raimi. 2014. Implications of shale gas development for climate change. Environmental Science \& Technology 48:8360-8368. http://dx.doi.org/10.1021/es4046154

O'Hara, S., M. Humphrey, J. Andersson-Hudson, and W. Knight. 2016. Public perception of shale gas extraction in the UK: from positive to negative. University of Nottingham, Nottingham, UK. http://www.scribd.com/doc/131787519/public-perceptions-of-shalegas-in-the-UK-September-2015-pdf

Olmstead S. M., L. A. Muehlenbachs, J.-S. Shih, Z. Chu, and A. J. Krupnick. 2013. Shale gas development impacts on surface water quality in Pennsylvania. Proceedings of the National Academy of Sciences of the USA 110:4962-4967. http://dx.doi. org/10.1073/pnas. 1213871110

Paredes, D., T. Komarek, and S. Loveridge. 2015. Income and employment effects of shale gas extraction windfalls: evidence from the Marcellus region. Energy Economics 47:112-120. http:// dx.doi.org/10.1016/j.eneco.2014.09.025

Perry, S. L. 2012. Development, land use, and collective trauma: the Marcellus Shale gas boom in rural Pennsylvania. Journal of Culture and Agriculture 34:81-92. http://dx.doi.org/10.1111/ j.2153-9561.2012.01066.x

Sagener, N. 2016. European Parliament's backing of fracking outrages critics. Eur Activ. com, 27 October. [online] URL: https:// www.euractiv.com/section/energy/news/parliaments-backing-of-frackedgas-outrages-critics/

Sanchez, N. II, and D. C. Mays. 2015. Effect of methane leakage on the greenhouse gas footprint of electricity generation. Climatic Change 133:169-178. http://dx.doi.org/10.1007/s10584-015-1471-6

Sangaramoorthy, T., A. M. Jamison, M. D. Boyle, D. C. PayneSturges, A. Sapkota, D. K. Milton, and S. M. Wilson. 2016. Placebased perceptions of the impacts of fracking along the Marcellus Shale. Social Science \& Medicine 151:27-37. http://dx.doi. org/10.1016/j.socscimed.2016.01.002
Schafft, K., and C. Biddle. 2015. Opportunity, ambivalence, and youth perspectives on community change in Pennsylvania's Marcellus Shale region. Human Organization 74:74-85. http://dx. doi.org/10.17730/humo.74.1.6543u2613xx23678

Schrag, D. P. 2012. Is shale gas good for climate change? Daedalus 141(2):72-80. http://dx.doi.org/10.1162/DAED a 00147

Scott, K. 2012. Measuring wellbeing: towards sustainability? Routledge, New York, New York, USA.

Singh, R. K., H. R. Murty, S. K. Gupta, and A. K. Dikshit. 2009. An overview of sustainability assessment methodologies. Ecological Indicators 9:189-212. http://dx.doi.org/10.1016/j. ecolind.2008.05.011

Souther, S., M. W. Tingley, V. D. Popescu, D. T. S. Hayman, M. E. Ryan, T. A. Graves, B. Hartl, and K. Terrell. 2014. Biotic impacts of energy development from shale: research priorities and knowledge gaps. Frontiers in Ecology and the Environment 12:330-338. http://dx.doi.org/10.1890/130324

Sovacool, B. K. 2014. Cornucopia or curse? Reviewing the costs and benefits of shale gas hydraulic fracturing (fracking). Renewable and Sustainable Energy Reviews 37:249-264. http://dx. doi.org/10.1016/j.rser.2014.04.068

Stedman, R. C. 2016. Subjectivity and social-ecological systems: a rigidity trap (and sense of place as a way out). Sustainability Science 11(6):891-901. http://dx.doi.org/10.1007/s11625-016-0388y

Thomas, M., N. Pidgeon, D. Evensen, T. Partridge, A. Hasell, C. Enders, B. Herr Harthorn, and M. Bradshaw. 2016. Public perceptions of hydraulic fracturing for shale gas and oil in the United States and Canada. WIREs Climate Change.

Ulanowicz, R. E., S. J. Goerner, B. Lietaer, and R. Gomez. 2009. Quantifying sustainability: resilience, efficiency and the return to information theory. Ecological Complexity 6:27-36. http://dx.doi. org/10.1016/j.ecocom.2008.10.005

Vengosh, A., R. B. Jackson, N. Warner, T. H. Darrah, and A. Kondash. 2014. A critical review of the risks to water resources from unconventional shale gas development and hydraulic fracturing in the United States. Environmental Science \& Technology 48:8334-8348. http://dx.doi.org/10.1021/es405118y

Vidic, R. D., S. L. Brantley, J. M. Vandenbossche, D. Yoxtheimer, and J. D. Abad. 2013. Impact of shale gas development on regional water quality. Science 340(6134). http://dx.doi. org/10.1126/science.1235009

Walker, B., and D. Salt. 2006. Resilience thinking: sustaining ecosystems and people in a changing world. Island Press, Washington, D.C., USA.

Wang, Q., X. Chen, A. N. Jha, and H. Rogers. 2014. Natural gas from shale formation - the evolution, evidences and challenges of shale gas revolution in United States. Renewable and Sustainable Energy Reviews 30:1-28. http://dx.doi.org/10.1016/j.rser.2013.08.065

Weber, C. L., and C. Clavin. 2012. Life cycle carbon footprint of shale gas: review of evidence and implications. Environmental Science and Technology 46:5688-5695. http://dx.doi.org/10.1021/ $\underline{\text { es } 300375 n}$ 
Weber, J. G. 2012. The effects of a natural gas boom on employment and income in Colorado, Texas, and Wyoming. Energy Economics 34:1580-1588. http://dx.doi.org/10.1016/j. eneco.2011.11.013

Weigle, J. 2011. Resilience, community, and perceptions of Marcellus Shale development in the Pennsylvania wilds: reframing the discussion. Sociological Viewpoints 27:3-14.

Wigley, T. 2011. Coal to gas: the influence of methane leakage. Climatic Change 108:601-608. http://dx.doi.org/10.1007/ $\underline{\text { s10584-011-0217-3 }}$

Williams, L., P. Macnaghten, R. Davies, and S. Curtis. 2015. Framing 'fracking': exploring public perceptions of hydraulic fracturing in the United Kingdom. Public Understanding of Science 89-104. DOI: 10.1177/0963662515595159 http://dx.doi. org/10.1177/0963662515595159

Wilson, J., P. Tyedmers, and R. Pelot. 2007. Contrasting and comparing sustainable development indicator metrics. Ecological Indicators 7:299-314. http://dx.doi.org/10.1016/j.ecolind.2006.02.009

Zavala-Araiza, D., D. Lyon, R. A. Alvarez, V. Palacios, R. Harriss, X. Lan, R. Talbot, and S. P. Hamburg. 2015. Toward a functional definition of methane super-emitters: application to natural gas production sites. Environmental Science and Technology Letters 49:8167-8174. http://dx.doi.org/10.1021/acs.est.5b00133 